\title{
A PROTEÇÃO DAS GERAÇÕES FUTURAS DIANTE DOS DESASTRES NATURAIS NAS CONSTITUIÇÕES CONTEMPORÂNEAS
}

\section{Henrique Rosmaninho Alves}

Mestre em Direito Ambiental e Desenvolvimento Sustentável pela Escola Superior Dom Helder Câmara. Professor no Instituto Minas de Educação e Cultura - Imec. henrique_rosmaninhoalves@outlook.com

\section{Resumo}

Os desastres naturais constituem um problema ambiental contemporâneo que afeta diretamente a vida da população e a possibilidade de existência das futuras gerações. São fenômenos que se relacionam intimamente com o meio ambiente, em seus aspectos naturais, visto que emanam deles, mas também artificiais, uma vez que os fatores de vulnerabilização da sociedade aos impactos provenientes dos eventos adversos naturais geralmente decorrem da interferência antrópica. Buscou-se, ante a influência dos desastres naturais na sociedade contemporânea, identificar suas características e sua evolução material, social e jurídica. Neste ponto encontra-se o objetivo principal da pesquisa, qual seja, a investigação da regulamentação jurídica desse tipo de evento, adentrando nos seus aspectos constitucionais. Utilizou-se de uma pesquisa predominantemente jurídico-dogmática, na qual o marco teórico foram os textos de diferentes Constituições, principalmente o da Constituição da República de 1988. Conclui-se ao final pela existência de múltiplas espécies de abordagens constitucionais de proteção das gerações futuras ante os desastres naturais, destacando-se a abordagem pátria, para a qual se dedica maior atenção.

\section{Palavras-chave:}

Desastres naturais. Constituições. Gerações futuras.

\section{THE PROTECTION OF FUTURE GENERATIONS IN FACE OF NATURAL DISASTERS IN CONTEMPORARY CONSTITUTIONS}

\section{Abstract}

Natural disasters are a contemporary environmental issue that directly affects the lives of the population and the possibility of future generations. They are phenomena that are closely related to the environment in its natural and artificial aspects. The reason for those adverses events are the human interference in nature. This search has the intention to demonstrate the influence of natural disasters in contemporary society, identifing the characteristics of social and legal evolution. The main objective of the research is the investigation of legal regulation about natural disasters and entering in its constitutional aspects. We used predo- 
minantly legal and dogmatic methodology of research, in which the theoretical framework were the texts of different constitutions, especially the brazilian Constitution of 1988. The conclusion shows the existence of multiple types of constitutional approaches to protecting future generations in view of natural disasters. In this matter, we gave a particular attention to the Constitution of Brazil.

\section{Keywords:}

Natural disasters. Constitutions. Future generations.

\section{Sumário}

1 Introdução. 2 A Constitucionalização do Meio Ambiente e da Proteção das Gerações Futuras. 3 Interconectividade entre o Direito Fundamental ao Meio Ambiente e os Direitos Fundamentais à Saúde e à Vida. 4 A Segunda Geração dos Problemas Ambientais: os Desastres Naturais. 5 Os Desastres Naturais na Sociedade Contemporânea e a Racionalização dos Fenômenos Naturais Intensos. 5.1 Os Desastres Naturais na Sociedade Contemporânea. 6 A Constitucionalização da Proteção da População em Face dos Desastres Naturais. 6.1 Proteção Implícita. 6.2 Proteção Explícita. 6.3 Esforços Interpretativos para a Verificação da Proteção Constitucional das Futuras Gerações em Face do Crescimento dos Desastres Naturais. 7 Princípio da Eficiência na Administração Pública e da Progressividade do Pacto dos Direitos Econômicos, Sociais e Culturais, os Pilares da Vedação ao Retrocesso Socioambiental. 8 Conclusão. 9 Referências. 


\section{INTRODUÇÃO}

Os problemas ambientais decorrentes da poluição provocada pelos processos produtivos industriais e pelo consumismo do ser humano acarretaram grandes riscos para a sociedade contemporânea e para a posteridade. Esses riscos motivaram a criação de pactos internacionais, legislaçóes internas e a constitucionalização do meio ambiente como um direito fundamental.

Ao final do século 20 outro problema ambiental chamou a atenção dos Estados e da sociedade: a expansão da reincidência e dos danos provenientes do impacto de fenômenos naturais.

Os desastres naturais tornaram-se mais recorrentes e mais destruidores e novamente surgiu uma onda de regulamentaçáo internacional e nacional sobre fatores ambientais, todavia esta regulamentação não alcançou status constitucional de imediato, ficando relegada à legislação ordinária.

Embora majoritariamente regulada pela legislação ordinária a proteção da população diante dos desastres naturais, por vezes, e de distintos modos, foi englobada pela ordem constitucional.

Dessa forma, vislumbrando as divergências entre os diferentes métodos de proteção constitucional contra as catástrofes naturais, buscou-se ao longo da investigaçáo identificar os contornos das abordagens constitucionais acerca dos desastres naturais e das geraçóes futuras.

Para tanto, utilizou-se de uma metodologia jurídico-dogmática, focada nos sistemas constitucionais e nas legislaçóes internacionais, embora tenha-se tentando inserir aspectos sociológicos na construção do raciocínio, visando a facilitar a compreensão sobre as motivaçôes das alterações normativas.

No intuito de proporcionar coesão ao raciocínio desenvolvido, dividiu-se o estudo em seis itens, cada um deles destinado a um tema específico indispensável ao bom entendimento do tema posterior.

O primeiro item destina-se a demonstrar o processo que levou à constitucionalização do meio ambiente e da proteção das geraçóes futuras. Neste tópico expôs-se que anteriormente a essa constitucionalização o fundamento para proteger 
o meio ambiente emanava dos direitos à saúde e à vida. A relação entre esses direitos foi abordada então no item posterior, a fim de expor a proximidade de seus objetivos e conteúdos.

Ainda no segundo item elencou-se os fatores ambientais responsáveis por obstruir o gozo dos direitos em análise, em ordem cronológica, quais sejam, a poluição ambiental e a elevação dos desastres naturais respectivamente.

No terceiro tópico faz-se uma análise das características dos desastres naturais e da eclosão de normas voltadas a sua regulamentaçáo, para adiante, no quarto item, abordar a evolução dos desastres na História da humanidade, tanto no que respeita à magnitude e periodicidade dos eventos, quanto na mudança de compreensáo das suas causas pela sociedade. Nessa parte vislumbra-se os atuais contornos dos desastres naturais, evidenciando a sua influência na sociedade.

Passa-se então a estudar a proteção constitucional voltada a esse tipo de evento, nos itens seguintes, ou seja, no item quinto debruça-se sobre as modalidades de abordagens constitucionais relativas à proteção diante dos desastres, seja ela destinada à geração presente ou à futura.

Menciona-se nesse ponto as diversas técnicas de interpretação do texto constitucional e a necessidade de o intérprete fazer um esforço hermenêutico para conseguir alcançar a compreensão da extensão do conteúdo da norma constitucional pátria referente aos desastres e às geraçóes vindouras.

Por fim aponta-se o princípio da vedaçáo ao retrocesso socioambiental como um instrumento de efetivação da proteção das futuras geraçóes contra os desastres naturais e apresenta-se sua fundamentação constitucional.

Os desastres naturais constituem um tema pouco estudado pelo Direito, e os parcos estudos existentes não versam sobre sua relação com a Constituição e com as futuras geraçóes. Em decorrência disto, acredita-se que o presente texto possa agregar bons conhecimentos para a ainda pequena doutrina nacional de direito dos desastres, e também para os estudiosos do Direito Ambiental. 


\section{A CONSTITUCIONALIZAÇÃO DO MEIO AMBIENTE E DA PROTEÇÃO DAS GERAÇÕES FUTURAS}

A Constituição de um país no sistema do civil law é a principal norma jurídica vigente, da qual emanam os valores sociais e jurídicos de maior adesão e os limites a serem observados pelas demais legislaçôes, visto que referida norma possui capacidade de vincular as legislaçōes futuras aos nortes estabelecidos em seu texto.

Como a norma mais importante do ordenamento jurídico, as matérias que são tratadas em seu bojo, via de regra, revestem-se de extrema importância para a vida social e para o bom funcionamento do Estado e da economia nacional.

A relevância das normas constitucionais desdobra-se em duas características peculiares: a proeminência e a preeminência.

Proeminência designa a hierarquia superior da norma constitucional e a necessidade de obediência das normas inferiores as suas disposiçóes, enquanto a preeminência caracteriza a posição de destaque quanto à publicidade desse tipo de norma, ou seja, a maior visibilidade e consequente respeitabilidade dessa modalidade normativa (BENJAMIN, 2007).

O meio ambiente enquanto espaço físico (natural ou artificial) que abriga e rege a vida em todas as suas formas é notadamente dotado da relevância necessária para motivar sua inserção nos textos constitucionais, uma vez que se trata de um elemento indispensável para a concretizaçáo e qualidade da vida humana.

Contemporaneamente quase a totalidade das Constituiçôes de países ocidentais que adotam o sistema do civil law dispôem sobre a temática ambiental.

O processo de constitucionalização do meio ambiente, porém, iniciado em âmbito global em meados da década de 70, necessitou embasar-se em uma considerável crise ambiental originada após a Segunda Guerra, que resultou em maciça poluição ambiental, riscos incalculáveis e eventos paradigmáticos de consolidação de danos ambientais. 
A prevenção inserida em grande parte das Constituiçôes como um princípio do Direito Ambiental em muitos casos não foi o fundamento inicial da inserção da temática nas Cartas Magnas, mas sim a recuperação e inibição de novos comportamentos degradantes.

Ao final da Segunda Guerra Mundial a demanda por produtos, proveniente do processo de reconstruçáo dos países envolvidos, ocasionou um processo de acelerada industrialização do Ocidente, que somada à evolução dos processos tecnológicos de produção em massa resultaram em uma crise ambiental sem precedentes.

A poluiçáo emanada dos processos produtivos alcançou patamares alarmantes, interferindo diretamente na qualidade da vida humana e provocando danos ambientais de magnitude até então inimagináveis.

Alguns desses danos ambientais caracterizaram-se pela extensão espacial de abrangência, visto que afetaram continentes inteiros; já outros apresentaram à população a interdependência dos fatores ambientais, ao levar seus efeitos a todo o globo terrestre.

Entre os problemas ambientais que compuseram a crise ambiental do século 20 pode-se citar a poluição de rios internacionais, a depleção da camada de ozônio, os acidentes nucleares e industriais de Chernobyl e Bophal, a poluição do ar nas grandes metrópoles (Londres, Sáo Paulo, Tóquio), o desmatamento e a perda de biodiversidade.

Ante a crescente poluição e consolidação de danos ambientais que atingiram diretamente a vida humana, em 1972 realizou-se em Estocolmo, na Suécia, a $1^{\text {a }}$ Conferência Internacional sobre o Meio Ambiente, a qual teve ampla adesão por parte dos países.

Nessa Conferência discutiram-se diversos aspectos da relação da humanidade com o meio ambiente e da conduta dos países e da coletividade para a promoção de uma maior proteção ambiental. Na ocasião foram estabelecidos diversos direitos e deveres em um documento internacional que posteriormente ficou conhecido como Declaração de Estocolmo. 
Apesar de a Declaração de Estocolmo não possuir força coercitiva, ela indubitavelmente influenciou os ordenamentos jurídicos dos países signatários, podendo-se apontar como frutos dessa influência a constitucionalização da proteção ambiental nas Constituiçôes da Grécia (1975), Portugal (1976), Espanha (1978) e Brasil (1988) (COSTA, 2010).

A inserção da proteção ambiental nas Constituiçôes dos países supracitados não inovou em absoluto o ordenamento jurídico vigente, pois esses já continham instrumentos legais esparsos de proteção ambiental (Código de Águas, Código Florestal, entre outros), mas elevou o status do tema a uma posição de maior visibilidade capaz de ensejar não apenas efeitos jurídicos diretos, mas também uma maior conscientização da população acerca da essencialidade da matéria.

Salienta-se que a crise ambiental motivadora da constitucionalização do meio ambiente trouxe à tona o questionamento sobre a temporalidade dos direitos coletivos. Os riscos provenientes dos processos produtivos de massa e da adoção de novas tecnologias, os quais expuseram toda a população, rompendo as barreiras espaciais dos potenciais danos ambientais, e a exploração acelerada dos recursos naturais não renováveis, fizeram emergir uma reflexão sobre os efeitos dessa exploração desenfreada na qualidade de vida ou mesmo na possibilidade de existência de futuras geraçóes.

Dessa reflexão surgiu ainda na Declaração de Estocolmo a figura das futuras geraçóes como titulares de direitos, aptos a limitar o modelo de desenvolvimento empregado até entáo.

Os princípios 2 e 5 da Declaraçáo de Estocolmo sobre o Ambiente Humano determinaram a necessidade de preservação dos recursos naturais (ar, água, solo) e ecossistemas em benefício das geraçôes presentes e vindouras, e a exploração racional dos recursos não renováveis, de modo a evitar seu esgotamento futuro (NAÇÓES UNIDAS, 1972).

O pioneirismo da supracitada Declaração novamente gerou frutos ao influenciar legislaçóes nacionais que igualmente inseriram o direito das futuras geraçóes em suas constituiçôes e legislaçóes. 
No caso brasileiro a Constituição da República de 1988 adotou a atribuiçấo de direitos às geraçóes futuras no caput do artigo 225 ao dispor que todos têm direito ao meio ambiente ecologicamente equilibrado, constituindo dever do poder público e da coletividade defendê-lo e preservá-lo para as presentes e futuras geraçóes (BRASIL, 1988).

A manutenção de um meio ambiente ecologicamente equilibrado para as geraçóes que estão por vir lhes possibilitará o acesso a recursos não renováveis e à qualidade ambiental, fatores responsáveis por proporcionar maior conforto e bem-estar, pelo viés da preservação da saúde, do acesso a bens de consumo e da convivência com a natureza.

Os direitos fundamentais à saúde e à vida inclusive já foram utilizados para justificar a proteção ambiental. Em tempos idos, anteriormente à constitucionalização do tema, juízes e doutrinadores fundamentavam nesses direitos a existência de uma proteção implícita das Constituições ao meio ambiente. Pode-se mencionar neste sentido a afirmativa do ministro José Celso de Mello sob a vigência da Constituiçẫo de 1969: "A tutela jurídica do meio ambiente decorre da competência legislativa sobre defesa e proteção da saúde” (MELLO FILHO, 1984, p. 40).

O direito ao meio ambiente salubre de fato está intrinsecamente ligado aos direitos à saúde e a vida, por revelar-se como verdadeiro requisito para o usufruto desses dois aspectos. Diversos autores abordaram a intimidade entre esses direitos, o que far-se-á a seguir para esclarecer os contornos e peculiaridades dessa relação.

\section{INTERCONECTIVIDADE ENTRE 0 DIREITO FUNDAMENTAL AO MEIO AMBIENTE E OS DIREITOS FUNDAMENTAIS À SAÚDE E À VIDA}

Para tratar da interconectividade entre os direitos fundamentais à saúde, ao meio ambiente e à vida cumpre iniciar esclarecendo o conceito de direito fundamental. 
Como não é o objetivo do presente estudo promover análises conceituais, não será realizada neste momento uma discussão profunda sobre o tema, bastando mencionar que os direitos fundamentais são aqueles elencados no texto constitucional. ${ }^{1}$

Contemporaneamente ambos os direitos supracitados estấo elencados na Constituição da República, embora, como já mencionado, nem sempre foi esse o cenário constitucional pátrio.

A Constituição da República de 1988 dispóe sobre o direito à vida no artigo $5^{\circ}$, sobre o direito à saúde no artigo $6^{\circ}$ e dedica todo um capítulo ao meio ambiente, estabelecendo-o como um direito fundamental no artigo 225.

O direito ao meio ambiente ecologicamente equilibrado constitui-se em um direito de titularidade difusa, à qual todos, indeterminadamente, fazem jus. Este direito desdobra-se em múltiplos aspectos, abarcando o direito a viver em ambiente salubre, livre de contaminação; a conviver com a natureza, englobando essa a biodiversidade (fauna, flora) e os ecossistemas naturais, e a ter preservados os aspectos culturais materiais e imateriais.

Entre esses desdobramentos, todos relacionam-se intimamente com o direito à vida, compreendido este não apenas como o direito de sobreviver, mas sim como o direito de viver com dignidade, ao passo que, com relação ao direito à saúde, o direito a viver em ambiente descontaminado apresenta relaçáo de maior proximidade.

Compreende-se o direito à saúde utilizando como paradigma a conceituação de saúde presente no preâmbulo da Constituição da Organização Mundial da Saúde - OMS - de 1946. Neste documento consta a definição de saúde como "o completo bem-estar físico, mental e social e não apenas a ausência de doença". Nesse sentido teria o direito à saúde duas facetas: uma coletiva e a outra individual (ORGANIZAÇÃO MUNDIAL DA SAÚDE, 1946).

1 André de Carvalho Ramos sustenta que "parte da doutrina comumente considera que o termo 'direitos humanos' serve para definir os direitos estabelecidos em tratados internacionais sobre a matéria, enquanto a expressão 'direitos fundamentais' delimitaria aqueles direitos do ser humano, reconhecidos e positivados pelo Direito Constitucional de um Estado específico". A definição dos conceitos de ambas as expressóes já atingiu um considerável consenso, sendo que vários doutrinadores, como Péres Luño e Höffe, compactuam da definição adotada por André de Carvalho Ramos. 
Como direito individual seria a prerrogativa que o ser humano tem de acessar um ambiente que lhe permita um completo bem-estar físico, mental e social, além de obter assistência médica em casos de doença. No aspecto coletivo o direito à saúde imprime ao poder público o dever de fiscalizar as condutas capazes de provocar a proliferação de doenças, limitando o comportamento humano e interferindo diretamente por meio de medidas preventivas, como a vacinação obrigatória, obrigatoriedade de isolamento de pessoas portadoras de determinadas doenças, entre outros (DALLARI, 1988).

A similaridade entre os direitos ao meio ambiente ecologicamente equilibrado e o direito à saúde é ainda mais notória quando se analisa a história da definição do conceito de saúde.

Hipócrates, filósofo grego do século $4^{\mathrm{o}}$ a.C., apontava a influência das cidades e dos hábitos cotidianos dos habitantes sobre o seu estado de saúde (HIPÓCRATES, 1950). Em consonância com ele, Paracelsus, médico alemão do século 16 ressaltava a interferência do mundo exterior (leis físicas da natureza e fenômenos biológicos) e a necessidade de sua consideração para a adequada percepção do funcionamento do organismo humano (PARACELSUS, 1941). Três séculos depois o filósofo alemão Engels, ao examinar as condições de vida e de trabalho dos operários ingleses, constatou o mesmo que Hipócrates 23 séculos antes, enfatizando, no entanto, a influência dos ambientes de trabalho no estado de saúde das populaçốes (ENGELS, 1986).

Sueli Gandolfi Dallari, professora da Faculdade de Saúde Pública da Universidade de São Paulo, salienta a experiência de Paracelsus, o qual, "devido a sua experiência como mineiro pôde mostrar a relação de certas doenças com o ambiente de trabalho" (DALLARI, 1988).

A referida autora destaca o debate ocorrido entre diferentes correntes de pensamento para a definição do conceito de saúde:

De um lado, grupos marginais ao processo de produçáo que viviam em condiçóes de vida miseráveis, enfatizavam a compreensão da saúde como diretamente dependente de variáveis relacionadas ao meio ambiente, ao trabalho, à alimentação eà moradia. A incidência de tuberculose, por exemplo, era acentuadamente mais elevada nas camadas sociais com menos renda. Por outro lado, a descoberta dos 
germes causadores de doença e seu subseqüente isolamento, que possibilitou o desenvolvimento de remédios específicos, falava a favor da conceituação da saúde como ausência de doenças (DALLARI, 1988).

Percebe-se claramente a relaçáo entre o direito ao meio ambiente ecologicamente equilibrado e o direito à saúde em decorrência da aptidão de um meio ambiente sadio em proporcionar bem-estar físico, interaçóes sociais agradáveis e consequentemente bem-estar mental, além de náo atuar como vetor de doenças e ofertar suprimentos para o tratamento de múltiplas enfermidades.

Abordada a relação saúde-meio ambiente, cumpre demonstrar os contornos da relação entre o direito ao meio ambiente ecologicamente equilibrado e o direito à vida.

Parte-se do entendimento de que vida "é o espaço de tempo em que se mantém a organização dos seres viventes" (BRASIL, 1987, p. 1.816).

O direito à vida, portanto, designa a prerrogativa inalienável de usufruir desse espaço de tempo com dignidade, sendo esta composta por aspectos como autonomia, proteção contra tortura e tratamento degradante, seja ele físico ou psicológico, e gozo de bens de consumo necessários a possibilitar a busca da felicidade (BARROSO, 2013).

O direito à vida é previsto na Declaração Universal dos Direitos Humanos de 1948 (artigo 3º), e na quase totalidade das Constituiçóes de países ocidentais, destacando-se a Constituição de Portugal de 1976 (artigo 24), a Constituição da Espanha de 1978 (artigo 15) e a Constituição do Brasil de 1988 (artigo 5º).

Canotilho destaca que o direito à vida engloba não apenas o direito de viver com dignidade, mas exige das autoridades e dos outros indivíduos que se abstenham de praticar atividades nocivas ao bem da vida (2001).

Compreende-se entre essas atividades nocivas não apenas as agressóes diretas perpetradas por indivíduos e pelo poder público à vida alheia, mas também as interferências no ambiente capazes de comprometer as condiçóes de subsistência.

As alteraçóes no meio ambiente capazes de afetar o direito à vida podem dividir-se em duas classes: graduais e abruptas. Na primeira classificação enquadra-se a poluição emanada dos processos produtivos industriais e dos hábitos cotidia- 
nos, que resultam em perda da qualidade do ar, poluição hídrica, contaminação de alimentos, depleção da camada de ozônio, entre outros. Esta modalidade de alteração sepulta inúmeras pessoas ao redor do globo, em razão de enfermidades respiratórias, câncer de pele, mortalidade infantil decorrente da inacessibilidade à água potável, etc.

As alterações abruptas são os denominados desastres, que se dividem em duas classes e revelam uma disparidade na relevância da atuação humana para sua concretização: desastres tecnológicos e desastres naturais.

Os desastres tecnológicos "são aqueles originados de condiçóes tecnológicas ou industriais, incluindo acidentes, procedimentos perigosos, falhas na infraestrutura ou atividades humanas específicas, que podem implicar em perdas humanas ou outros impactos à saúde", além de poderem causar prejuízos ambientais e econômicos (BRASIL, 2012).

Inúmeros foram os desastres tecnológicos ao longo da humanidade que provocaram centenas de óbitos. Beatriz de Souza Costa inclusive aponta como motivação para a realização da Conferência de Estocolmo o desastre tecnológico ocorrido na bacia de Minamata - Japão (COSTA, 2013).

Nesse evento, a empresa petroquímica Chisso despejava toneladas de efluentes diretamente na bacia de Minamata, da qual eram retirados os peixes e frutos do mar que constituíam a base da alimentação da população local. O resultado da ingestão prolongada de alimentos contaminados com mercúrio e outras substâncias tóxicas foi uma epidemia de problemas mentais e a morte de mais de 800 pessoas (COSTA, 2013).

Destaca-se também, entre os desastres tecnológicos a explosão da fábrica de substâncias químicas de Oppau (1921), o incêndio na mina de carvão Benxihu, na Manchúria (1942), explosão dos tanques de armazenamento de resíduos radioativos em Kyshtym, na Rússia (1957), explosão na estação química em Flixborough, no Reino Unido (1974), emissão tóxica na estação química da Hoffmann - La Roche Icmesa de Seveso (1976), explosão de tanque da fábrica de pesticidas Union Carbide em Bophal-Índia (1984), explosão do reator 4 da usina nuclear de Chernobyl (1986), explosóes da usina petroquímica de Jilin, na China (2005), entre outros (BROWN et al., 2012). 
No que respeita aos desastres naturais, a Resolução Normativa no 1 de 2012 do Ministério da Integração Nacional, no parágrafo $2^{\circ}$ do artigo $7^{\circ}$, os conceitua como "aqueles causados por processos ou fenômenos naturais que podem implicar em perdas humanas ou outros impactos à saúde, danos ao meio ambiente, à propriedade, interrupção dos serviços e distúrbios sociais e econômicos”" (BRASIL, 2012).

Ocorre que como salientam Daniel Farber et al. (2010), em decorrência da gigantesca influência antrópica no ambiente, não existem mais desastres exclusivamente naturais.

De fato a interferência antrópica quase sempre é responsável por fragilizar a capacidade de resistência do meio ambiente aos impactos intensos, ou seja, por aumentar a vulnerabilidade dos espaços (remoção de vegetação de encostas, topos de morros e matas ciliares), ou por elevar a exposição da população a riscos (ocupaçáo do leito maior dos rios e de encostas com declividade acima de 45 graus). Não obstante, consideram-se naturais aqueles eventos que tiveram como causa imediata um fenômeno natural.

Em todas as hipóteses de alteraçôes ambientais supracitadas (poluição ou degradação gradual, desastres tecnológicos ou naturais) o meio ambiente atua como fator de obstrução do direito à vida, o que denota a extrema conexão entre este e o direito ao meio ambiente ecologicamente equilibrado.

Vale lembrar que a vida se desenvolve no meio ambiente, o qual constitui-se no espaço físico, natural ou artificial, que a abriga e rege em todas as suas formas.

Beatriz Souza Costa apresenta entendimento que se coaduna com o exposto ao sustentar que o direito ao meio ambiente sadio é uma extensão do direito à vida (2013, p. 101).

Insta mencionar a liçáo de Antônio Augusto Cançado Trindade sobre a concepção moderna do direito à vida e suas implicaçôes na esfera ambiental:

O caráter fundamental do direito à vida torna inadequados enfoques restritos do mesmo em nossos dias; sob o direito à vida, em seu sentido moderno, não só se mantém a proteção contra qualquer privação arbitrária da vida, mas além disso encontram-se os Estados no dever de "buscar diretrizes destinadas a assegurar o acesso aos meios de sobrevivência” a todos os indivíduos e todos os povos. Neste 
propósito, têm os Estados a obrigação de evitar riscos ambientais sérios à vida, e de pôr em funcionamento "sistemas de monitoramento e alerta imediato" para detectar tais riscos ambientais sérios e "sistemas de ação urgente" para lidar com tais ameaças (1999, p. 75).

A relação entre os direitos fundamentais aqui abordados implica, conforme Trindade, deveres de atuação do poder público, no caso em análise, precisamente em situaçóes de riscos ambientais capazes de afetar a vida humana.

Abordar-se-á a seguir as características da segunda geração dos problemas ambientais e as suas consequências para a vida das futuras geraçóes.

\section{A SEGUNDA GERAÇÃO DOS PROBLEMAS AMBIENTAIS: OS DESASTRES NATURAIS}

Desastres naturais sáo os resultados danosos provocados pelos impactos provenientes de fenômenos naturais intensos. Como esses fenômenos ocorrem desde os primórdios da humanidade, durante toda a História o ser humano conviveu com os desastres naturais.

Eventos como tempestades severas com grandes períodos de retorno, erupçóes vulcânicas, terremotos, avalanches, estiagem, deslizamentos de terra, entre outros, são fenômenos naturais, decorrentes da dinâmica do ecossistema em que se inserem, sempre aconteceram e sempre acontecerão nos locais propícios a sua incidência (terremotos em falhas geológicas, deslizamentos na Serra do Mar, por exemplo).

Essas ocorrências possuem características que elevaram o seu potencial destruidor, como a imprevisibilidade. $\mathrm{O}$ advento da revolução tecnológica de fato mitigou consideravelmente esta característica, tornando boa parte dos fenômenos hidrológicos previsíveis. Mesmo os fenômenos passíveis de monitoramento, no entanto, por vezes demonstram a falibilidade dos sistemas de controle, concretizando-se em momentos e locais inesperados e com intensidades diversas das previstas. 
A imprevisibilidade somada ao caráter abrupto desses acontecimentos dificulta o atendimento de emergência, a criação de medidas de prevençáo e evacuação e resulta em grandes prejuízos materiais e humanos.

Salienta-se que nem todos os fenômenos causadores de desastres naturais são abruptos, alguns deles caracterizam-se por serem graduais, como as inundaçôes gradativas, estiagens, desertificação, erosão, entre outros.

Independentemente do caráter abrupto ou gradual e do grau de previsibilidade dos eventos adversos, em condiçóes naturais, eles reincidem em consideráveis espaços de tempo. A interferência antrópica no ambiente em alguns casos influi diretamente para o aumento da reincidência de fenômenos naturais intensos, como a impermeabilização das bacias hidrográficas que aumenta a vazão dos cursos d'água, em decorrência do maior volume do escoamento superficial, provocando enchentes e inundações (TUCCI, 2005).

A interferência antrópica no ambiente, causadora da poluição ambiental e consequente degradaçáo da qualidade do ar, da água, e responsável pela contaminaçáo de alimentos, provocou consideráveis danos à população e suscitou a atenção da sociedade civil organizada e dos Estados em virtude de constituírem fatos até então inexistentes na História da humanidade.

Os danos decorrentes da poluição emanada dos processos produtivos industriais constituíram a primeira geração dos problemas ambientais, aos quais a humanidade foi exposta em razão de sua atuação no planeta. Por serem fenômenos até então inexistentes, ganharam notoriedade anteriormente aos desastres naturais, visto que esses, embora com menos recorrência, sempre afetaram os seres humanos.

A primeira geração dos problemas ambientais indubitavelmente foi a responsável pela edificação dos sistemas jurídicos de proteção ambiental nacionais e internacionais. As convençôes internacionais de meio ambiente (Estocolmo/1972, Rio-92, etc.), por exemplo, ocorreram em razão da expansão desses problemas ambientais relativos à produção e ao consumo global.

Ao final da década de 80, outro movimento de proteção ambiental surge no âmbito da $\mathrm{ONU}$ voltado à gestáo dos desastres naturais. Este movimento atenta-se à elevação do número de ocorrências desses fenômenos e relaciona-os com as mudanças climáticas e as intervençóes humanas nos ecossistemas (GOMES, 2012). 
Em 1989 é aprovada a Resolução 44/236 pela Assembleia Geral das Naçóes Unidas, a qual nomeia a década de 90 como a Década Internacional para a Redução dos Desastres Naturais (NAÇÓES UNIDAS, 1989).

Esse movimento contou com grande adesão internacional e culminou na realização de três Conferências Internacionais para a Gestão dos Desastres Naturais, ocorridas em Yokohama no ano de 1995, Hyogo em 2005 e Sendai em 2015, as quais resultaram em documentos internacionais contendo estratégias para a prevençáo dos fenômenos naturais intensos e para a mitigaçáo dos danos daqueles eventos que se concretizarem. Em 1995 foi firmada a "Estratégia de Yokohama", em 2005 o "Marco de Ação de Hyogo" e em 2015 o "Marco de Ação de Sendai" (GOMES, 2012).

Os estudos realizados ao longo dos últimos 25 anos constataram a elevação do número de desastres naturais no planeta e sua relação de causalidade com alguns fatores, como as alteraçóes climáticas, apontadas pela Escola de Geociências da Universidade de Edinburgh como responsáveis diretas pelo advento da intensificação das tempestades na América do Norte (MIN et al., 2011).

O Brasil, não obstante seja um país naturalmente privilegiado, livre de erupçóes vulcânicas e de abalos sísmicos consideráveis, também sofreu com a elevação da ocorrência de enchentes e deslizamentos, o que levou o país a se aparelhar administrativa e juridicamente para a gestão desses eventos.

Proliferaram os estudos sobre as causas das enchentes urbanas e dos deslizamentos de encostas, fenômenos responsáveis pelos desastres naturais mais presentes no país, e realizou-se um diagnóstico nacional dos danos e das características dos desastres nacionais, por intermédio do Centro Universitário de Estudos e Pesquisas sobre Desastres da Universidade Federal de Santa Catarina e do Centro Nacional de Gerenciamento de Riscos e Desastres, departamento vinculado ao Ministério da Integração Nacional.

A constatação científica do aumento da intensidade e recorrência dos desastres naturais, somada ao aumento dos danos anualmente causados por esses eventos permite sua classificação como a segunda geração de problemas ambientais. 
De fato pode-se argumentar que os desastres naturais seriam os primeiros problemas ambientais da História da humanidade, afinal estiveram presentes desde os primórdios, causando prejuízos à população, ao passo que a poluição degradadora é relativamente recente. Os desastres naturais ocorridos anteriormente à era da poluição emanada dos processos industriais, no entanto, eram acontecimentos absolutamente naturais, não havia contribuição humana para sua concretização, como acontece contemporaneamente.

É justamente a contribuição antrópica para o dano o elemento adotado no presente estudo para caracterizar um fato como problema ambiental. Como a contribuição antrópica para a concretização dos desastres naturais aconteceu posteriormente à poluiçấo ambiental, resultante dos processos humanos de produção e consumo, classificam-se estes como problemas ambientais de primeira geração e aqueles como problemas ambientais de segunda geraçáo.

\section{OS DESASTRES NATURAIS NA SOCIEDADE CONTEMPORÂNEA E A RACIONALIZAÇÃO DOS FENÔMENOS NATURAIS INTENSOS}

Conforme abordado anteriormente, os desastres naturais ocorrem desde os mais remotos tempos. Durante grande parte da História humana esses eventos eram atribuídos à ira divina, pela descrença da população.

Múltiplas são as mitologias que contêm algum episódio em que um desastre natural é atribuído ao descontentamento de algum deus. Assim ocorre com a mitologia judaica no dilúvio bíblico, com a mitologia grega no episódio de Baucis e Filêmon, com a mitologia Maia na grande inundaçáo provocada pelo deus $\mathrm{Hu}$ racán, entre outras.

O episódio crucial para a desmistificação desses eventos ocorreu em 1755 no grande terremoto de Lisboa. Neste evento o secretário de Estado, Sebastiāo José de Carvalho e Melo, posteriormente intitulado Marquês de Pombal, inovou a ordem vigente até entâo ao inserir as primeiras medidas de gestão de riscos de desastres no atendimento aos feridos e durante a reconstrução de Lisboa (SHRADY, 2011). 
Em $1^{\circ}$ de novembro de 1755 , no Dia de Todos os Santos, por volta de 9 horas da manhã Lisboa sentiu três grandes abalos sísmicos que provocaram o desabamento de milhares de prédios, diversos focos de incêndio e acarretaram em múltiplos tsunamis que varreram a capital portuguesa (SHRADY, 2011).

Estima-se que morreram nesse evento mais de 10 mil pessoas de um total de 250 mil que habitavam a mais importante cidade lusitana da época (SHRADY, 2011).

Extremamente abalado com o evento, que inicialmente fora atribuído à ira divina, o desesperado rei Dom José I recebeu, em meio ao maior desastre da História de Portugal, a visita do secretário de Estado, Sebastião José de Carvalho e Melo (posteriormente conhecido como Marquês de Pombal) (SHRADY, 2011).

A conversa que ocorreu entre ambos mudou a História da humanidade no que tange à administração dos desastres naturais. $\mathrm{O}$ rei, angustiado com o desmoronamento da capital indagou a Carvalho: "O que deve ser feito para enfrentar essa imposição da justiça divina?” e obteve como resposta: "Enterrar os mortos e alimentar os vivos" (SHRADY, 2011, p. 31).

Dom José, embora muito religioso, ansiava por uma resposta sensata e como Carvalho também havia sido poupado por Deus do desastre, ele o enxergou como um agente da providência divina que fora enviado para ajudar num momento tão cruel (SHRADY, 2011).

Investido pelo rei da autoridade necessária para confrontar o desastre, Carvalho começou então uma grande e duradoura jornada rumo à reconstrução de Lisboa (SHRADY, 2011).

Carvalho imediatamente após encontrar-se com o rei voltou a Lisboa e encontrou uma cidade em chamas, extremamente destruída, com pilhas de mortos e feridos e uma multidão de pessoas abandonando as suas dependências (SHRADY, 2011). 
As medidas iniciais de Carvalho foram verdadeiras açóes de resposta ao desastre. Foram construídos patíbulos e instituído um sistema verbal rápido de julgamento e execução sumária para quem fosse pego saqueando, o que apesar da crueldade "cessou com brevidade o escândalo de tantos roubos", nos dizeres de José Moreira de Mendonça (SHRADY, 2011, p. 52).

No que respeita à tarefa de alimentar os vivos, o secretário de Estado agiu com extrema firmeza e sensatez:

Carvalho ordenou o estabelecimento de pontos de distribuição de comida nas praças do Terreiro do Paço e da Ribeira, onde mantimentos que escaparam ilesos das chamas, peixes do Tejo e comestíveis de aldeias distantes foram recolhidos pela guarda armada e distribuídos de forma equitativa. Por toda a cidade, foram instaladas às pressas, cozinhas de campanha e fornos de páo ao ar livre. [...] os navios que chegavam com cargas de gráos, peixes e carne foram obrigados a vender sua mercadoria com isenção de taxas. Em uma tentativa de frear a exploração, os donos de loja foram obrigados a cobrar os preços que vigoravam antes do desastre; aqueles que desobedeciam acabavam em grupos de trabalho forçado, limpado os entulhos. "Com estas sábias providências", escreveu Moreira de Mendonça, "não houve em parte alguma fome, como se temia nos primeiros dias" (SHRADY, 2011, p. 52).

Outra tarefa de extrema importância era o enterro dos mortos. O medo de um surto da peste era intenso, o cheiro desagradável dos mortos emanava por toda a extensão da capital, no entanto o incêndio provocado pelos tremores de terra, embora destruísse boa parte da cidade, incinerava milhares de corpos e acabou contribuindo para evitar uma epidemia.

Embora o incêndio tenha colaborado para evitar a peste, milhares de mortos ainda permaneciam nas ruas e o enterro dos cadáveres era prioridade, afinal se tal processo fosse retardado, poderia ocasionar numa grande proliferação de doenças.

Ocorre que a remoção dos mortos, conforme os hábitos religiosos vigentes à época, era impossível devido às circunstâncias. Diante deste cenário: 
Carvalho requereu do Patriarca, José Cardinal Manuel da Câmara d'Atalaia, permissão para abrir mão da prática tradicional e sem demora sepultar os mortos no mar. $\mathrm{O}$ patriarca sabiamente deu sua permissão e, a partir de 3 de novembro, barcaças carregadas com mortos até o topo das amuradas, seguiram pelo Tejo rumo ao mar aberto, onde mergulharam a carga em um túmulo aquático (SHRADY, 2011, p. 56).

Essas três açóes de Carvalho, juntamente com a benevolência de diversos moradores que não tiveram suas casas atingidas e abriram suas portas para abrigar os sobreviventes, foram cruciais para evitar um número ainda maior de mortes e uma debandada que poderia ter comprometido a reconstrução da capital (SHRADY, 2011).

Após a desordem inicial os lisboetas começaram a refazer suas vidas. $\mathrm{Na}$ ocasião "Carvalho proibiu qualquer nova construção de pedra até que todos os entulhos tivessem sido retirados e fossem redigidos um novo código de normas construtivas e um plano urbano" (SHRADY, 2011, p. 60). Tal medida iniciou a fase de reconstrução da área atingida, sendo notório que visou a evitar construções irregulares e prevenir futuros desastres, como contemporaneamente deve ser feito na fase de reconstrução de uma área afetada.

Passada a fase inicial de resposta ao desastre, a atribuição à vontade divina como causa do terremoto e a consequente necessidade de arrependimento pregada pelos clérigos, dado que alguns consideravam um sacrilégio a tentativa de reconstruir a capital portuguesa, constituiu-se no grande empecilho para o avanço das obras de reconstrução.

Nesse sentido vale mencionar as palavras do padre Gabriel Malagrida, em seu texto "Juízo da verdadeira causa do terramoto (sic)":

Sabe pois, oh Lisboa, que os únicos destruidores de tantas casas, e Palácios, os assoladores de tantos Templos, e Conventos, homicidas de tantos seus habitadores, os incêndios devoradores de tantos tesouros, os que a trazem ainda tão inquieta, e fora da tua natural firmeza, não são Cometas, não são Estrelas, não são contingências, ou causas naturais, mas são unicamente os nossos intoleráveis pecados. [...] É escandaloso fingir que o terramoto (sic) foi apenas um aconteci- 
mento natural, pois se isso for verdade não há a necessidade de se arrepender e tentar evitar a fúria de Deus, e nem mesmo o próprio demônio poderia inventar uma idéia falsa mais apropriada para nos levar todos à ruína irreparável (1756).

Carvalho sabia da influência que o clero exercia sobre toda a sociedade portuguesa, inclusive sobre a realeza, e ansiava por limitar o poder da Igreja no país. Teve como seus grandes inimigos nessa seara a Companhia de Jesus, e seu principal expoente o padre Gabriel Malagrida.

É importante mencionar que não foram apenas explicações teológicas que o terremoto motivou, na verdade, posteriormente a ele, e em decorrência, multiplicaram-se estudos científicos no intuito de explicar as causas do evento.

Importantes pensadores tiveram uma abordagem científica do evento, como Jean Jacques Rousseau e Immanuel Kant. Kant inclusive escreveu três tratados sobre terremotos considerando-os acontecimentos científicos desprovidos de qualquer caráter moral, um deles intitulado "História e descrição natural dos estranhos fenômenos relacionados com o terremoto que, no final do ano de 1755, abalou uma grande parte da Terra”, de 1756 (SHRADY, 2011).

Kant acreditava que embaixo da Terra haviam fendas cheias de ventos, água e fogo que quando estimulados provocavam os terremotos. Embora desconhecesse as reais causas dos terremotos (movimentação das falhas geológicas) os estudos da época contribuíram significativamente para uma visão mais racional dos fenômenos naturais, o que permitiu uma gestão muito mais efetiva dos desastres naturais (KANT, 1755).

Um dos grandes momentos para o processo de desvinculaçáo do divino da origem dos fenômenos naturais aconteceu três meses após o terremoto, quando "Carvalho publicou um inquérito contendo 13 perguntas, uma espécie de questionário sismológico, que foi enviado às dioceses de Portugal inteiro. As perguntas tentavam estabelecer os parâmetros do desastre segundo critérios puramente científicos [...]" e conforme Shrady, "são praticamente as mesmas perguntas que qualquer sismólogo contemporâneo consciencioso faria, sem o benefício dos instrumentos de calibragem modernos" (SHRADY, 2011, p. 172-173). 
O questionário era completamente desprovido de qualquer referência à metafísica ou à moral. As perguntas não continham alusóes a augúrios ou atos pecaminosos, "não havia qualquer menção a Deus ou à ira divina". Eram indagaçôes acerca dos efeitos do terremoto, tanto naturais quanto econômicos e sociais, "mostravam claramente uma preocupação com a administração moderna do desastre, inquirindo acerca das medidas tomadas pelas autoridades ou da situação de estoques de comida”. Uma concepção racional do evento era preponderante, "não somente Deus era excluído do quadro, mas agora um Estado esclarecido havia entrado em cena” (SHRADY, 2011, p. 171-173).

Carvalho chegou a reinaugurar Lisboa, em 1775, embora a obra não estivesse acabada e ainda existissem bairros destruídos espalhados pela capital. O bairro da Baixa (contemporaneamente conhecido como Baixa Pombalina) no dia 6 de junho foi inaugurado, com uma estrutura moderna, ruas amplas e a majestosa estátua do rei Dom José I.

$\mathrm{O}$ argumento da ira divina mostrou-se impertinente e a utilização da razão como fator de ponderação para a gestáo dos desastres naturais nasceu, a duras penas, no século 18 sob a batuta do Marques de Pombal.

Conforme Shrady, "Se Lisboa de fato oferece uma lição para os desastres que hoje enfrentamos, é a de que o homem está no centro de nossa resposta ao desastre natural, e não a providência, a metafísica ou a ira de um Deus vivo" (2011, p. 244).

Cumpre salientar que mesmo no século 21 ainda perduram as concepçóes teológicas da origem dos desastres naturais, como é possível perceber do pronunciamento do arcebispo aposentado de Nova Orleans, Philip M. Hannan, quando da passagem do Furacáo Katrina:

Como cidadáos, somos responsáveis pela atitude sexual, pelo desrespeito aos direitos da família, pelo vício das drogas, pelo assassinato de 45 milhóes de futuras crianças, pelo comportamento escandaloso de alguns padres - entấo temos de entender que certamente o Senhor tem direito de aplicar um castigo [...] Chegamos a um grau de imoralidade que nunca antes atingimos. E o castigo veio na forma do Katrina, tanto quanto do Rita (apud SHRADY, 2011, p. 243-244). 
A racionalização dos desastres naturais, iniciada em 1755, permitiu a inserção de diversos fatores de prevenção e medidas de mitigação na gestão dos riscos de desastres.

A prevenção sob a perspectiva teológica era absolutamente desnecessária, porque qualquer atuação humana seria insuficiente diante do poder de Deus. Já sob a lógica científica, açóes de prevenção poderiam minimizar a vulnerabilidade dos territórios ao impacto dos diversos eventos naturais adversos. Inúmeras medidas de prevenção foram adotadas inclusive no projeto de reconstrução do bairro da Baixa, de autoria do engenheiro militar Eugênio dos Santos.

Contemporaneamente, a prevenção constitui-se no fator de maior eficácia para evitar o acontecimento ou a quantidade dos danos nos desastres naturais, fundamenta a criação de sistemas de monitoramento e alerta antecipado e a adoção de normas de construçáo voltadas para aumentar a resistência a impactos, responsáveis por evitar anualmente milhares de mortes nos eventos adversos.

\subsection{OS DESASTRES NATURAIS NA SOCIEDADE CONTEMPORÂNEA}

Contemporaneamente com toda a evolução provocada pela racionalização da compreensão dos fenômenos causadores dos desastres naturais, pelos investimentos em estudos científicos e pelos esforços internacionais no estabelecimento de açóes de prevenção, preparaçáo e resposta emergencial, a humanidade ascendeu a um estágio de considerável compreensão das causas e dos fatores de vulnerabilizaçáo dos territórios aos impactos naturais.

Existem em funcionamento eficientes sistemas de monitoramento dos fenômenos e de alerta à população. São dominadas diversas técnicas estruturais de prevenção, como estruturas resistentes a terremotos, construçóes de diques e barragens de detenção, e reconhecem-se as causas responsáveis por diminuir a capacidade de resistência dos ecossistemas aos impactos provenientes de eventos adversos de origem natural.

Ainda assim, mesmo com o grande avanço conquistado no âmbito dos conhecimentos de causalidade e gestão de riscos, os desastres naturais aumentam paulatinamente a sua incidência e a quantidade dos danos provocados. 
Essa elevação do número de desastres naturais deve ser atribuída aos fatores de ampliação dos riscos, os quais são características marcantes da sociedade contemporânea plenamente em voga na lógica socioeconômica do século 21 .

Délton Winter de Carvalho e Fernanda Dalla Libera Damacena apontam cinco fatores como responsáveis pela ampliação dos riscos, quais sejam: condições econômicas modernas; crescimento populacional e tendência demográfica; decisões acerca da ocupação do solo; destruiçáo de infraestruturas naturais e precariedade ou ausência de infraestrutura construída e mudanças climáticas (CARVALHO; DAMACENA, 2013).

Carlos Tucci enfatiza a responsabilidade da ocupação inadequada do solo e da sua impermeabilização para a concretização de enchentes urbanas (2005).

Wigold Bertoldo Schäffer et al. ressaltam a importância da supressão das infraestruturas naturais para a ocorrência dos deslizamentos de terra na Serra do Mar no desastre sucedido na região serrana fluminense em 2011 (2011).

Todos esses fatores elencados pelos especialistas contribuem para fragilizar o território e consequentemente ampliam a exposição da população aos impactos.

Salienta-se a interligação entre todos os fenômenos suscitados. O crescimento populacional, no caso brasileiro, ocorreu com a urbanização de modo extremamente célere no século 20. Num período de 50 anos, entre 1940 e 1990, houve um incremento populacional de 106 milhóes de pessoas (INSTITUTO..., 2010). Este excedente populacional, muitas vezes proveniente de famílias de baixo poder aquisitivo oriundas do interior do país, destinou-se às áreas urbanas e sem condiçóes de adquirir imóvel urbanizado procedeu às invasóes situadas em áreas desprovidas de valor econômico devido à localização inadequada para o uso residencial.

Inúmeras invasóes situam-se em morros com inclinação acima de $45^{\circ}$ e em leitos maiores de cursos d'água, ambientes naturalmente suscetíveis a deslizamentos e inundaçóes. 
As ocupaçóes nessas localidades promoveram a retirada das infraestruturas naturais que preveniam os deslizamentos (vegetaçóes de encostas responsáveis pela fixação do solo) e as inundaçóes (matas ciliares as quais retêm os resíduos sólidos das águas do escorrimento superficial e evitam o assoreamento dos rios) (SCHÄFFER et al., 2011).

O crescimento populacional, somado à tendência de urbanização, aumenta a impermeabilização da bacia hidrográfica. Com o solo impermeabilizado por massa asfáltica, telhados e concreto, há uma elevaçáo do escorrimento superficial das águas pluviais e da sua velocidade de deslocamento, o que acarreta a antecipaçáo do pico de cheia, proporcionando maior volume de água nos cursos d'água do que sua capacidade de vazão e resultando em enchentes e inundaçóes (TUCCI, 2005).

É notória a íntima relação existente entre o crescimento populacional, a tendência à urbanização, a ocupação inadequada do solo e a retirada de infraestruturas naturais. Esses fatores fomentam um ao outro e por mais que no Brasil tenham iniciado no século 20 , todos eles ainda estão presentes na primeira década do século 21 .

Como o dano ambiental muitas vezes não é instantâneo, a vulnerabilização provocada pelos fatores supraexpostos acumulou-se ao longo do século passado, e ante os fenômenos naturais intensos entrou em colapso, resultando na elevação da incidência e dos danos provenientes dos desastres naturais.

Para ilustrar essa expansão dos desastres naturais utilizar-se-á um diagnóstico realizado no Brasil pelo Centro Universitário de Estudos e Pesquisas sobre Desastres da Universidade Federal de Santa Catarina.

Primeiramente realizou-se uma análise do período de 1991 a 2010 por intermédio do Atlas Brasileiro de Desastres Naturais 1991-2010.

É importante mencionar que há um considerável crescimento do número de eventos adversos na segunda metade do período analisado: na década de 19912000 aconteceram 27\% do total de desastres ocorridos no período total, ou seja, na década de 2001-2010 o número de desastres naturais mais do que dobrou, sendo responsável por $73 \%$ dos eventos percebidos durante o período total (SANTA CATARINA, 2012). 
No período em comento foram verificados consideráveis danos materiais e humanos à população brasileira. Nessas duas décadas, apenas em decorrência do impacto de fenômenos naturais intensos ocorreram 3.404 óbitos, 399.734 pessoas adquiriram enfermidades, 17.406 ficaram gravemente feridas, 70.441 ficaram levemente feridas, houve 5.652 desaparecidos, 1.155 .599 desabrigados e 3.168.973 desalojados (SANTA CATARINA, 2012).

Salienta-se que o crescimento do número de desastres, bem como a paulatina edição de normas internacionais sobre o tema, levaria o país a adotar sua primeira legislação sobre desastres em 2010, por intermédio da Lei no 12.340 .

Embora a magnitude dos desastres variasse conforme as características socioambientais do local impactado, tais eventos abrangeram todo o território nacional durante o interregno de tempo pesquisado.

Após o ano de 2010, o Centro Nacional de Gerenciamento de Riscos e Desastres passou a elaborar anualmente estudo sobre os desastres naturais ocorridos no país, abarcando a magnitude dos danos, tipos de evento adversos percebidos, distribuição espacial dos eventos, entre outros fatores concernentes ao tema.

O Anuário Brasileiro de Desastres Naturais de 2011 apontou a ocorrência de 1.094 óbitos, 672 feridos, 115.539 desabrigados, 655.952 desalojados, 5 desaparecidos e 12.535 .401 afetados, num total de 2.370 municípios atingidos. O elevado número de danos explica-se pela ocorrência de um grande desastre na região serrana do Estado do Rio de Janeiro, no qual deslizamentos de terra decorrentes das fortes chuvas provocaram grande destruição (BRASIL, 2012).

No ano de 2012 novamente foi elaborado o Anuário Brasileiro de Desastres Naturais, o qual também identificou os danos ocorridos no período e o tipo de evento responsável. Nesse ano as mortes caíram drasticamente e houve um decréscimo no número de desabrigados e desalojados, no entanto, o número de afetados saltou em aproximadamente 25\% (BRASIL, 2013).

No ano de 2013 o Anuário constatou 183 óbitos, 175.609 desabrigados 516.405 desalojados, 205 desaparecidos e 18.557.233 afetados (BRASIL, 2014). 
Percebe-se uma variação considerável no número de óbitos ao longo do triênio 2011-2013, tendo uma queda de mais de 90\% do primeiro para o segundo ano e depois uma elevação de quase $100 \%$. Embora o número de mortes tenha variado bastante, a quantidade de óbitos anualmente chama a atenção.

Tabela 1 - Danos provocados por desastres naturais no período de 2011 a 2013 e média anual dos danos do período de 1991 a 2010

\begin{tabular}{|c|c|c|c|c|c|c|c|}
\hline $\begin{array}{l}\text { ANO/TIPO } \\
\text { DE DANO }\end{array}$ & $\begin{array}{l}\text { ÓBI } \\
\text { TOS }\end{array}$ & $\begin{array}{l}\text { ENFER- } \\
\text { MIDADE }\end{array}$ & $\begin{array}{l}\text { DESABRI- } \\
\text { GADOS }\end{array}$ & $\begin{array}{l}\text { DESALOJA } \\
\text { DOS }\end{array}$ & $\begin{array}{l}\text { D E S A - } \\
\text { PARECI- } \\
\text { DOS }\end{array}$ & \begin{tabular}{|l|} 
F E R I - \\
DOS
\end{tabular} & AFETADOS \\
\hline 2011 & 1.094 & 10.561 & 115.539 & 655.952 & 5 & 672 & 12.535 .401 \\
\hline 2012 & 93 & 39.227 & 110.286 & 507.021 & 1.044 & 9.168 & 16.977 .614 \\
\hline 2013 & 183 & 159.696 & 175.609 & 516.405 & 105 & 8.573 & 18.557 .233 \\
\hline \begin{tabular}{|l|} 
TRIÊNIO \\
$2011-2013$ \\
\end{tabular} & 1370 & 209.484 & 401.434 & 1.679 .378 & 1.154 & 18.413 & 48.070 .248 \\
\hline $\begin{array}{l}\text { Média anual } \\
\text { do período de } \\
1991 \text { a } 2010\end{array}$ & 170,2 & $19.986,70$ & $57.779,95$ & $158.448,65$ & 282,6 & $4.392,35$ & $4.811 .016,95$ \\
\hline $\begin{array}{l}\text { Média anual } \\
\text { do triênio }\end{array}$ & 456,66 & 69.828 & $133.811,33$ & $559.792,66$ & 584 & $6.137,66$ & 16.023 .416 \\
\hline
\end{tabular}

Fonte: Elaboração própria.

O mais preocupante, neste quadro, é o número de desabrigados e desalojados. Vê-se, no estudo, que anualmente mais de meio milhão de pessoas foram obrigadas a se ausentarem de suas casas em virtude de desastres naturais.

Comparando a média anual dos danos no triênio 2011-2013 com a média anual verificada no período de 1991-2010 constata-se uma elevação na magnitude dos danos provocados, o que ao menos indica um crescimento da vulnerabilidade do território nacional a eventos adversos de origem natural.

No âmbito internacional ocorreram desastres naturais de grande monta no início do século 20, reforçando o argumento de elevação da ocorrência desses fenômenos. Destacam-se entre esses o terremoto seguido de tsunami na regiáo de Tohoku, no Japão, em 2011; o terremoto no Haiti em 2010; o ciclone Nargis em Mianmar em 2008 e o terremoto seguido por tsunami no Oceano Índico em 2004.

Em 2011, no início da tarde de 11 de março, a aproximadamente 72 quilômetros da costa nordeste da ilha de Honshu ocorreu um terremoto com duração de 6 minutos e magnitude máxima 9 na escala Richter, que produziu tsunamis de até 38 metros de altura que invadiram 10 quilômetros de território e atingiram a Usina 
Nuclear de Fukushima, provocando um risco de explosão nuclear que colocou a comunidade internacional em alerta. Nesse evento vieram a óbito cerca de $30 \mathrm{mil}$ pessoas e a estimativa de reconstrução do território afetado ultrapassou um trilhão de reais (BROWN, 2012, p. 86).

O Haiti, país localizado na Ilha de São Domingos, é um dos países mais pobres do planeta, carregando ainda o fardo de sua vulnerabilidade geológica a sismos. No ano de 2008, quatro terremotos haviam matado 800 pessoas no período de um mês naquele país, o que veio a se tornar irrisório ante o terremoto ocorrido em 12 de janeiro de 2010 (7.0 na escala Richter), responsável pela morte de 150.000 a 250.000 pessoas (BROWN, 2012, p. 86).

O terremoto do Haiti é um excelente exemplo de como um desastre natural pode acabar com anos de desenvolvimento econômico em apenas algumas horas, visto que boa parte da infraestrutura de Porto Príncipe, conquistada ao longo de anos, destruiu-se no sismo (BROWN, 2012, p. 86).

O Nargis foi possivelmente o ciclone mais mortal da História da humanidade, causando a morte de 150.000 a 1.000 .000 de pessoas em Mianmar em 2 de maio de 2008. A denominada "Tempestade Tropical Ciclônica Muito Severa Nargis" - abreviada para ciclone Nargis - "formou-se sobre o golfo da Bengala em abril, previu-se que o Nargis atingiria o sudeste da Índia ou Bangladesh. Em vez disso, ele passou causando danos relativamente pequenos no Sri Lanka (4.500 desabrigados pela enchente) antes de ganhar força e chegar a Burna (Mianmar)" com ventos de $215 \mathrm{~km} / \mathrm{h}$ (BROWN, 2012, p. 86).

O ciclone Nargis é um excelente exemplo da imprevisibilidade dos fenômenos naturais, mesmo nos casos em que exista uma margem de previsibilidade.

Outro evento natural marcante foi o terremoto e tsunami no Oceano Índico em 2004. Um megaterremoto de 9.3 na escala Richter aconteceu no fundo do mar na costa oeste de Sumatra, um dia após o Natal (26 de dezembro), provocando tsunamis de 30 metros de altura que invadiram dois quilômetros de território. Estima-se que 230.000 pessoas morreram, entre elas 9.000 turistas (BROWN, 2012, p. 86). 
É notória, ante todo o exposto, a influência dos desastres naturais na vida das pessoas. Esta influência, resultante da magnitude e reincidência dos impactos, fomentou a elaboração de um considerável aparelhamento internacional de prevençâo e assistência emergencial no âmbito da ONU, bem como incentivou a proliferação de legislaçóes e sistemas nacionais de monitoramento e alerta precoce.

A prevenção e resposta a esses eventos adversos de origem natural não tiveram, no entanto, posição de destaque nas Constituiçóes, ficando relegadas ao âmbito da legislação ordinária. O Brasil é um típico caso de legislação infraconstitucional, embora contenha dispositivos constitucionais que abordam a matéria de maneira direta e indireta.

Demonstrar-se-á a seguir o modo como ocorre a proteção constitucional sobre os desastres naturais nas Constituiçóes contemporâneas, enfatizando a Constituição da República de 1988.

\section{A CONSTITUCIONALIZAÇÃO DA PROTEÇÃO DA POPULAÇÃO DIANTE DOS DESASTRES NATURAIS}

A proteçẫo da população diante dos desastres naturais nos ordenamentos jurídicos nacionais, via de regra, ocorre por intermédio da legislação infraconstitucional.

As Constituiçôes promovem essa proteçáo majoritariamente de modo indireto, por meio dos mandamentos de preservação e defesa do meio ambiente e da necessidade de adequado ordenamento do solo urbano.

Há, no entanto, Constituiçôes que abordam de modo direto o tema dos desastres naturais, contendo em seu texto dispositivos destinados especificamente à finalidade de proteçâo diante desses eventos.

Existem, portanto, duas modalidades constitucionais de proteção ante os impactos provenientes dos eventos adversos de origem natural: a proteçâo explícita e a implícita. 


\subsection{PROTEÇÃO IMPLÍCITA}

A proteção implícita diante dos desastres naturais ocorre por intermédio dos mandamentos constitucionais de defesa do meio ambiente, de garantia do direito à moradia e da necessidade de se promover o adequado ordenamento do solo urbano.

A preservação dos ecossistemas e processos ecológicos essenciais, por exemplo, salvaguarda as infraestruturas naturais prestadoras de serviços ecossistêmicos capazes de prevenir a concretização de desastres. As Áreas de Preservação Permanente são um nítido caso de elementos naturais capazes de serviços ecossistêmicos de prevenção, destacando-se sua função de estabilização geológica e de manutenção do ciclo hidrológico.

$\mathrm{O}$ adequado ordenamento do solo urbano visa, entre outros fatores, a eliminar ocupaçôes em áreas de risco, como encostas de morros e leitos de expansão dos cursos d'água, e consequentemente diminuir a exposição da população a enchentes e deslizamentos de terra.

Essa modalidade de proteção não aborda diretamente o tema desastre natural, não contém em seus dispositivos essa terminologia, mas proporciona a proteção da população por meio da atuação direta nos fatores de vulnerabilização a esses eventos.

No caso da Constituição do Brasil pode-se apontar entre os dispositivos que promovem esta proteção implícita os artigos 182 e 225, caput, e $\$ 1^{\circ}$, I.

\subsection{PROTEÇÃO EXPLÍCITA}

A proteção explícita em relação aos desastres naturais ocorre quando a Constituição adota dispositivos que abordem diretamente este tema. Não é necessário que contenha em seu texto a expressão "desastre natural", mas sim que regulamente aspectos diretamente relacionados a eles, como enchentes, alagamentos, terremotos, entre outros. 
O artigo 389 da Constituição do Equador de 2008 é um exemplo de proteção constitucional explícita. Referido dispositivo regulamenta a gestão dos riscos em seus incisos e determina no caput que se promova a proteção da população diante dos desastres por meio da prevenção, recuperação e da minimização das condiçôes de vulnerabilidade.

Art. 389. El Estado protegerá a las personas, las colectividades y la naturaleza frente a los efectos negativos de los desastres de origen natural o antrópico mediante la prevención ante el riesgo, la mitigación de desastres, la recuperación y mejoramiento de las condiciones sociales, económicas y ambientales, con el objetivo de minimizar la condición de vulnerabilidad (EQUADOR, 2008).

$\mathrm{Na}$ Constituição da República de 1988 há dispositivo de proteção explícita, embora notoriamente tímido, razáo pela qual muitos o desconhecem. Trata-se do artigo 21, inciso XVIII, que atribui à União a competência para promover a defesa em razão das calamidades públicas.

Art. 21. Compete à Uniáo:

XVIII - planejar e promover a defesa permanente contra as calamidades públicas, especialmente as secas e as inundaçōes (BRASIL, 1988).

A ordem constitucional brasileira historicamente atribui a tarefa de planejar e promover a proteção contra os desastres naturais à União. A Constituição de 1967 foi a pioneira a fazê-lo, determinando à União a competência para "organizar a defesa permanente contra as calamidades públicas, especialmente a seca e as inundaçóes" em seu artigo $8^{\circ}$, texto similar ao do artigo 21 , inciso XVIII da atual Constituição.

Importa mencionar que a Constituição de 1967 com a redação dada pela Emenda Constitucional no 1 de 1969, ainda continha, em seu artigo 172, disposição que versava sobre os desastres naturais sob a dicção de "intempéries e calamidades". Referido artigo, no entanto, objetivava salvaguardar interesses econômicos provenientes do agronegócio e não interesses mais fundamentais, como a manutenção da saúde e da vida da população exposta a risco. 
Art. 172. A lei regulará, mediante prévio levantamento ecológico, o aproveitamento agrícola de terras sujeitas a intempéries e calamidades. $\mathrm{O}$ mau uso da terra impedirá o proprietário de receber incentivos e auxílios do Governo (BRASIL, 1967).

Não obstante a proteção constitucional explícita ante os desastres naturais da Constituição da República de 1988 seja demasiadamente tênue, existe nesse texto constitucional uma complexa proteção implícita emanada dos artigos que preveem a proteção do meio ambiente, a ordenação do espaço urbano, a função social da propriedade, as competências dos entes federativos e a obediência da administração pública ao princípio da eficiência.

\subsection{ESFORÇOS INTERPRETATIVOS PARA A VERIFICAÇÃO DA PROTEÇÃO CONSTITUCIONAL DAS FUTURAS GERAÇÕES DIANTE DO CRESCIMENTO DOS DESASTRES NATURAIS}

A atual ordem constitucional brasileira prevê a proteção das gerações futuras no caput do artigo 225, o qual se destina a instituir o direito ao meio ambiente ecologicamente equilibrado. Protege as geraçóes futuras ao estendê-lo a elas.

A extensão do direito ao meio ambiente equilibrado para as futuras geraçóes visa a salvaguardar a saúde e a possibilidade de existência dessas, apresentando, portanto, profunda relação com o direito à vida, tanto no seu aspecto meramente existencial quanto no aspecto de garantia do gozo de dignidade.

A proteção das geraçóes futuras e a gestão dos desastres naturais estão intrinsecamente interligados, em sentidos amplo e restrito.

Em sentido amplo todas as pessoas estão expostas a algumas modalidades de desastres naturais, principalmente os provenientes de alteraçóes climáticas provocadas pelo processo de produçáo humano, como as temperaturas extremas. Esses desastres podem inviabilizar a vida em determinados momentos e assim impedir que as futuras geraçóes venham a se constituir. 
O sentido restrito atinge um nicho menor da população, o qual está mais exposto aos efeitos negativos dos impactos provenientes dos fenômenos naturais intensos. Referido nicho é composto pelas populaçóes de baixa renda residentes em áreas de risco periodicamente atingidas.

Desastres provocados por fenômenos sazonais, como as enchentes, deslizamentos e inundaçóes, os quais estão diretamente ligados ao período chuvoso, afetam anualmente as mesmas localidades, em razão da propensão natural dessas ao acontecimento dos eventos adversos supracitados. É o caso, por exemplo, das encostas de morros e calhas de expansão dos rios, ocupadas, via de regra, por populaçóes de baixa renda, que desprovidas de condiçôes de adquirir imóveis urbanizados, dirigem-se a áreas sem valor imobiliário, em que a fiscalização do poder público é precária, e ali instalam suas casas mediante invasóes ou loteamentos clandestinos (CONDE, 1992).

Essa população superexposta aos riscos de desastres naturais não raras vezes convive com os danos deles advindos. É o que se constata diante da reincidência desses eventos em um mesmo local.

A título de ilustraçáo, fazemos referência que a regiáo do Morro do Baú no município de Ilhota, duramente castigada pelas chuvas em novembro de 2008, foi novamente atingida pela forte chuva que caiu na noite de 21.01.2011, resultando no alagamento de casas, destruição de pontes, danos a residências e perdas nas lavouras de arroz às margens dos cursos d'água. Cerca de 70\% das obras de infra-estrutura que haviam sido refeitas após a tragédia de 2008 foram novamente destruídas, segundo a prefeitura, que estima que R \$ 12 milhóes dos R 17 milhões investidos desde entáo foram pelo ralo (SCHÄFFER et al., 2011, p. 10).

É importante salientar os ensinamentos de Herman Benjamin. Para o autor em análise "a ocorrência de chuvas torrenciais e a consequente elevação do nível de água dos riachos e rios é natural, sempre existiu e sempre existirá. Ou seja, onde houve enchente uma vez, mais cedo ou mais tarde, haverá novamente (apud SCHÄFFER et al., 2011, p. 25). 
A periodicidade dos eventos adversos nos mesmos locais póe em risco a existência de futuras gerações de um nicho bem específico da população, afinal são as mesmas famílias as afetadas ao longo dos anos.

Salienta-se que esse risco exacerbado à existência e dignidade das futuras geraçóes dessa população é consequência do descaso do poder público, que conforme Raquel Rolnik, a segregou do planejamento urbano ocorrido no século 20 (ROLNIK, 1997).

De todo modo a identificação da proteção das gerações futuras diante dessa modalidade de desastres no corpo da Constituição exige esforço interpretativo, não obstante em três das quatro principais modalidades de interpretação (sistemática, teleológica, histórica, semântica) seja possível aferir a sua existência.

Por intermédio de análise sistemática constata-se a proteção das geraçôes futuras contra os desastres naturais nos artigos 225, 182 e 21, inciso XVIII.

O artigo 225 prevê expressamente o direito das geraçóes futuras ao meio ambiente ecologicamente equilibrado, o qual, por óbvio, não é exponencialmente sujeito a colapsos quando impactado por intempéries da natureza.

O artigo 182 determina ao poder público municipal a realização da política de desenvolvimento urbano no intuito de garantir o pleno desenvolvimento das funçôes sociais da cidade e garantir o bem-estar de seus habitantes. É no âmbito das cidades que se encontra a maior parcela da população residente em áreas de risco, portanto cabe ao município eliminar esse risco por meio das medidas cabíveis (relocalização da população, inserção de medidas estruturais, etc.). A convivência com considerável risco de desastres é incompatível com o bem-estar dos habitantes, evidenciando a necessidade de proteção da população diante desses riscos.

Por fim a competência da União prevista no artigo 21, inciso XVIII, combinada com o exposto no caput do artigo 225 revela a intenção da Constituição em salvaguardar a vida e dignidade das geraçôes futuras ante os impactos adversos das catástrofes naturais.

Utilizando-se uma interpretação teleológica, é possível identificar a intenção de proteção das geraçôes futuras contra os desastres tanto no artigo 182 quanto no artigo 225. A finalidade da garantia de um meio ambiente ecologicamente equili- 
brado inclui a extinção, na medida do possível, dos riscos de colapso. Equilíbrio e colapso são características opostas. Se o poder público e a coletividade, por meio de sua atuação protetiva, garantem o meio ambiente equilibrado, este não estará especialmente sujeito a desastres naturais nem no presente e nem no futuro.

Aplicando-se a análise teleológica ao artigo 182, conclui-se pela proteção das geraçôes futuras diante das catástrofes, em decorrência da exigência de promoção do bem-estar da população, o qual deverá ser garantido pela atuação do município no ordenamento de seu território. O bem-estar engloba a extinção da convivência com riscos de danos oriundos de eventos adversos naturais, e promovendo a possibilidade de concretização das futuras geraçóes das populaçóes expostas a riscos.

A interpretação histórica deve ser aplicada sobre a totalidade do texto constitucional para permitir a conclusão proposta, visto que se for destinada a um dispositivo específico não possibilitará a percepção da existência da proteção reivindicada.

Analisando-se todo o texto constitucional, historicamente desde a Constituição de 1967 há uma tímida intenção de proteger a população contra os efeitos dos desastres naturais por meio da competência da União em "organizar a defesa permanente contra as calamidades públicas, especialmente as secas e as inundaçóes" (BRASIL, 1967). Esta intenção somada aos esforços de constitucionalização do meio ambiente e da proteção das futuras geraçóes, resultante, no que Benjamin (2007) denomina de "ambientalização" da Constituição, atesta a existência implícita da proteção contra os desastres destinada àqueles que estáo por vir.

Com relação à análise semântica, de fato, por essa modalidade interpretativa não é possível identificar a proteção em voga, em razão de não haver dispositivos literais nesse sentido.

Acredita-se que a melhor forma de se interpretar o texto constitucional seja por meio da análise sistemática de seus dispositivos, pois ela permite a identificação da unidade constitucional, evitando percepçóes contraditórias e conclusóes dissonantes nas diversas partes do documento.

No caso da Constituição de 1988, parece inegável a sua intenção de promover a proteção das futuras geraçôes contra os desastres naturais, quando aplica-se sobre seu texto uma interpretação sistemática. 
A interpretação sistemática permite também a averiguaçáo de princípios constitucionais implícitos, como será demonstrado a seguir.

\section{PRINCÍPIO DA EFICIÊNCIA NA ADMINISTRAÇÃO PÚBLICA E DA PROGRESSIVIDADE DO PACTO DOS DIREITOS ECONÔMICOS, SOCIAIS E CULTURAIS, OS PILARES DA VEDAÇÃO AO RETROCESSO SOCIOAMBIENTAL}

O parágrafo $3^{\circ}$ do artigo $5^{\circ}$ da $\mathrm{CF} / 1988$ dispóe que "Os tratados e convençóes internacionais sobre direitos humanos que forem aprovados, em cada Casa do Congresso Nacional, em dois turnos, por três quintos dos votos dos respectivos membros, serão equivalentes às emendas constitucionais" (BRASIL, 1988).

O Pacto Internacional sobre Direitos Econômicos, Sociais e Culturais, adotado pela 21 a Sessão da Assembleia Geral das Naçóes Unidas, em 19 de dezembro de 1966 na cidade de San José, foi aprovado pelo Congresso Nacional por meio do Decreto Legislativo ${ }^{\circ} 226$, de 12 de dezembro de 1991 e promulgado pelo presidente da República mediante o Decreto no 591 em 6 de julho de 1992.

Referido pacto versa sobre direitos fundamentais de segunda dimensão (direitos sociais) e no item 1 do artigo $2^{\circ}$ contempla o princípio da progressividade no alcance de tais direitos ao estabelecer:

Art. $2^{\circ}$ - 1. Cada Estado Parte do presente Pacto compromete-se a adotar medidas, tanto por esforço próprio como pela assistência e cooperação internacionais, principalmente nos planos econômico e técnico, até o máximo de seus recursos disponíveis, que visem a assegurar, progressivamente, por todos os meios apropriados, o pleno exercício dos direitos reconhecidos no presente Pacto, incluindo, em particular, a adoção de medidas legislativas (NAÇÕES UNIDAS, 1966, grifo nosso).

José Adércio Leite Sampaio argumenta que "não se pode mais pensar [...] apenas na questão social a ser resolvida como se fosse um problema sem relação com as práticas de degradaçáo e de esgotamento dos recursos naturais", e sustenta que o princípio da vedação ao retrocesso "náo se atém apenas ao "social", avançando para sua projeção mais atual e imperiosa: socioambiental” (SAMPAIO, 2013, p. 410). 
Romeu Thomé afirma que o princípio da vedação ao retrocesso socioambiental deriva da cláusula de progressividade prevista no Pacto Internacional dos Direitos Econômicos, Sociais e Culturais, de 1966, "que determina aos Estados Pactuantes a implementação progressiva dos direitos humanos nele consagrados". Conforme este autor, "a cláusula de progressividade atribuída aos direitos sociais deve abarcar, necessariamente, também os mecanismos voltados à proteção ambiental" com a finalidade de proporcionar uma paulatina melhora "da qualidade ambiental e, consequentemente, da qualidade de vida de uma maneira geral" (THOMÉ, 2013, p. 92).

O princípio da vedação ao retrocesso ambiental constitui-se em uma norma que impede a diminuiçáo da proteção ambiental ofertada pelo Estado pela via legislativa ou administrativa, ou seja, proíbe a edição de leis que minorem a proteçáo ofertada ao meio ambiente ou a instituição de políticas públicas de igual teor.

José Adércio Leite Sampaio denomina de retrocesso eficacial a diminuição da proteção ofertada pelo Estado independentemente de mudança normativa, e de retrocesso normativo a redução da proteção existente no Direito Positivo, ao defender a existência dessas duas modalidades de retrocesso (2013).

Nota-se que independentemente da modalidade de retrocesso, se concretizado emanaria da atuação estatal, razão pela qual referido princípio visa a precipuamente controlar a conduta do poder público, seja do Legislativo ou do Executivo.

A fundamentação constitucional da existência do princípio da vedação ao retrocesso socioambiental não se restringe ao exposto no Pacto dos Direitos Econômicos, Sociais e Culturais e ao previsto no parágrafo $3^{\circ}$ do artigo $5^{\circ}$, mas abarca também o princípio da eficácia da administração pública, previsto no caput do artigo 37; a necessidade de promoçáo do bem-estar da populaçáo na execuçáo da política urbana, estabelecida no artigo 182; a garantia do direito ao meio ambiente ecologicamente equilibrado para as presentes e futuras geraçóes, e a atribuiçáo ao poder público (aqui também inserida a coletividade) para promover este direito, artigo 225 .

A atribuição ao poder público para proteger o meio ambiente, combinada com as competências constitucionais para tanto, e nesse aspecto, enfatizando-se a competência da Uniáo para planejar e promover a defesa contra as calamidades naturais, e também a competência dos municípios para realizar o adequado orde- 
namento do solo urbano, expóem a relevância da atuação da administração pública na função de promoção do direito ao meio ambiente ecologicamente equilibrado para as presentes e futuras geraçôes, o que inclui a sua proteção diante das catástrofes naturais.

Essa atuação da administração pública é estabelecida pela exigência de eficiência, a qual designa uma atuação que produza resultados satisfatórios, implicando uma paulatina melhora dos resultados alcançados, ou seja, numa progressão dos benefícios conquistados.

É justamente essa exigência de progressão dos benefícios, presente no princípio da eficiência do artigo 37 e no artigo $2^{\circ}$ do Pacto dos Direitos Econômicos, Sociais e Culturais, o fundamento maior do princípio da vedação ao retrocesso socioambiental, razão pela qual essas normas constituem os seus pilares.

A utilização do princípio da vedação ao retrocesso socioambiental na gestão dos riscos de desastres é de grande importância, visto que sua adoção pode impedir a redução de funcionários e equipamentos destinados à fiscalização das áreas de risco, ao monitoramento dos fenômenos naturais e ao alerta precoce das comunidades afetadas.

Tal princípio pode também fundamentar decisôes que impeçam novas instalaçóes em áreas de risco e obriguem o poder público a adotar medidas estruturais que reduzam o risco nessas comunidades. Deste modo atuará em consonância com a proteção das futuras geraçóes, ao garantir-lhes a possibilidade de existência.

É possível concluir, portanto, que o princípio da vedação ao retrocesso socioambiental constitui-se em um instrumento jurídico de proteção das futuras geraçóes diante dos desastres naturais com embasamento constitucional.

\section{CONCLUSÃO}

A elevação do número de desastres naturais, juntamente com o aumento de seu potencial destruidor, chamaram a atenção dos países em uma época em que a constitucionalização do meio ambiente e da proteção das geraçóes futuras ainda era recente. 
Os danos provocados pelos desastres naturais constituíram-se em um óbice para a concretização das futuras geraçôes, assim como a poluição emanada das indústrias.

Esforços da Organização das Naçôes Unidas para diminuir o número de afetados por desastres naturais culminaram na adoção, por diversos países, de normas regulamentadoras de gestáo de riscos, as quais visam a prevenir e mitigar os danos e ofertar assistência emergencial à população.

Essas normas internas de gestão de riscos, via de regra, não se encontravam na Constituição, embora alguns países como o Equador contemplassem o tema na sua Carta Magna.

Embora muitas Constituições não abordassem diretamente o tema das catástrofes, diversas continham dispositivos que indiretamente tentavam diminuir a vulnerabilidade da população a esses eventos.

Vislumbrou-se então duas modalidades de proteção constitucional contra desastres: proteção implícita e proteção explícita.

Essas modalidades de proteção exigem do intérprete um esforço para sua identificação.

No caso da Constituição do Brasil de 1988, diversas técnicas interpretativas permitem que se constate a proteção das geraçôes futuras contra os desastres naturais, no entanto a que o faz com maior clareza é a interpretação sistemática.

Isso ocorre porque a CF/1988 contém diversos dispositivos ao longo do seu texto que promovem essa proteçáo de maneira implícita, por meio dos dispositivos de proteção do meio ambiente; de ordenação do território urbano e de regulamentação da atuação da administração pública, que quando relacionados evidenciam a referida proteção, e por vezes, alguns instrumentos para sua efetivação, como é o caso do princípio da vedação ao retrocesso socioambiental na ordem constitucional pátria.

O princípio da vedação ao retrocesso socioambiental trata-se de um princípio constitucional implícito oriundo da combinação entre o princípio da eficiência e do dever do poder público de promover o direito ao meio ambiente ecologicamente equilibrado, e constitui-se em uma importante ferramenta de auxílio à gestáo de riscos de desastres, uma vez que proíbe a diminuição dos parâmetros de proteção 
ofertada, sejam eles normativos (por meio da proibição de aprovação de norma menos protetiva) ou eficaciais (mediante a vedação a diminuição da infraestrutura administrativa disponível, como equipamentos, verbas e máo de obra qualificada).

\section{REFERÊNCIAS}

BARROSO, Luís Roberto. A dignidade da pessoa humana no Direito Constitucional contemporâneo: a construção de um conceito jurídico à luz da jurisprudência mundial. $1^{\text {a }}$ reimpressão. Belo Horizonte: Fórum, 2013.

BENJAMIN, Antônio Herman. Direito Constitucional Ambiental Brasileiro. In: CANOTILHO, José Joaquim Gomes; LEITE, José Rubens Morato. Direito Constitucional Ambiental Brasileiro. São Paulo: Editora Saraiva, 2007.

BRASIL. Constituiçāo da República Federativa do Brasil de 1988. Brasília: Diário Oficial, 5 out. 1988.

. Constituição da República Federativa do Brasil de 1967. Brasília: Diário Oficial, 24 jan. 1967.

. Enciclopédia Britânica do. Dicionário brasileiro de língua portuguesa. São Paulo: Enciclopédia Britânica do Brasil, 1987. Vol. VIII.

. Ministério da Integração Nacional. Secretaria Nacional de Defesa Civil. Centro Nacional de Gerenciamento de Riscos e Desastres. Anuário brasileiro de desastres naturais: 2011. Brasília: Centro Nacional de Gerenciamento de Riscos e Desastres; Cenad, 2012.

. Ministério da Integração Nacional. Secretaria Nacional de Defesa Civil. Centro Nacional de Gerenciamento de Riscos e Desastres. Anuário brasileiro de desastres naturais: 2012. Brasília: Centro Nacional de Gerenciamento de Riscos e Desastres; Cenad, 2013.

. Ministério da Integraçấo Nacional. Secretaria Nacional de Defesa Civil. Centro Nacional de Gerenciamento de Riscos e Desastres. Anuário brasileiro de desastres naturais: 2013. Brasília: Centro Nacional de Gerenciamento de Riscos e Desastres. Cenad, 2014.

. Ministério da Integração Nacional. Secretaria Nacional de Defesa Civil. Instrução normativa $n^{\circ} 1$, de 24 de agosto de 2012. Estabelece procedimentos e critérios para a decretação de situação de emergência ou estado de calamidade pública pelos Municípios, Estados e pelo Distrito Federal, e para o reconhecimento federal das situaçóes de anormalidade decretadas pelos entes federativos e dá outras providências. Brasília: Diário Oficial, 25 ago. 2012. 
BROWN, David et al. 501 desastres mais devastadores de todos os tempos. Trad. Catharina Pinheiro. 1. ed. brasileira. São Paulo: Editora Lafonte, 2012.

CANOTILHO, José Joaquim Gomes. Direito constitucional e teoria da Constituiçâa. 4. ed. Coimbra: Almedina, 2001.

CARVALHO, Délton Winter de; DAMASCENA, Fernanda Libera. Direito dos desastres. Porto Alegre: Livraria do Advogado, 2013.

CONDE, Luiz Paulo. Cadernos de Ciência, São Paulo: Finep, n. 28, p. 13-15, jul./ago./ set. 1992.

COSTA, Beatriz Souza. Meio ambiente como direito à vida - Brasil, Portugal e Espanha. Belo Horizonte: O Lutador, 2010.

COSTA, Beatriz Souza. Meio ambiente como direito à vida - Brasil, Portugal e Espanha. 2. ed. Rio de Janeiro: Editora Lumen Juris, 2013.

DALLARI, Sueli Gandolfi. O direito à saúde. Revista de Saúde Pública, v. 22, n. 1, fev. 1988. Disponível em: <http://www.scielo.br/scielo.php?pid=S0034-89101988000100008\&script=sci_ arttext>. Acesso em: 18 jun. 2015.

ECUADOR. Constitución de la República del Ecuador de 2008. Disponível em: <http:// www.inocar.mil.ec/web/images/lotaip/2015/literal_a/base_legal/A._Constitucion_republica_ecuador_2008constitucion.pdf>. Acesso em: 16 jun. 2015.

ENGELS, F. A situação da classe trabalhadora na Inglaterra. São Paulo: Global Ed., 1986.

FARBER, Daniel et al. Disaster, law and policy. Nova York: Aspens Publishers, 2010.

GOMES, Carla Amado (Coord.) et al. Direito (s) das Catástrofes Naturais. Lisboa: Almedina, 2012.

HIPÓCRATES. The medical works of Hippocrates; a new translation from the original greek made especially for English readers by the collaboration of John Chadwick and W. N. Mann. Springfield, III. Thomas, 1950. p. 90-111.

INSTITUTO BRASILEIRO DE GEOGRAFIA E ESTATÍSTICA - IBGE. Primeiros resultados definitivos do Censo 2010: população do Brasil é de 190.755.799 pessoas. 2010 . Disponível em: < http://censo2010.ibge.gov.br/noticias-censo?busca=1 \&id=3\&idnoticia= 1866\&view=noticia $>$. Acesso em: 18 jun. 2015.

KANT, Immanuel. Geschichte und Naturbeschreibung der merkwürdigsten Vorfälle des Erdbebens, welches an dem Ende des 1755 sten Jahres einem grossen Theil der Erde erschüttert hat. Könisgberg, 1756, republicado em Kants Werke I. Berlim: Akademie Textausgabe, 1968. 
MALAGRIDA, Gabriel. Juizo da verdadeira causa do terremoto. Lisboa, 1756.

MELLO FILHO, José Celso de. Constituição Federal anotada. São Paulo: Saraiva, 1984.

MIN, Seung-Ki et al. Letter: Human contribution to more-intense precipitations extremes. Nature, n. 378, v. 470, p. 1-4, fev. 2011.

NAÇÓEES UNIDAS. Pacto Internacional dos Direitos Econômicos, Sociais e Culturais de 1966. Disponível em: <http://www.unfpa.org.br/Arquivos/pacto_internacional.pdf>. Acesso em: $10 \mathrm{dez} .2014$.

- Resolução no 44/236 da Assembléia Geral. Institui a década internacional para a redução de desastres naturais. 1989.

. Declaração de Estocolmo sobre o ambiente humano. 1972. Disponível em: <http:// www.silex.com.br/leis/normas/estocolmo.htm>. Aceso em: 18 de jun. 2015.

ORGANIZAÇÃO MUNDIAL DA SAÚDE. Constituição da Organização Mundial da Saúde de 1946. Disponível em: <http://www.direitoshumanos.usp.br/index.php/OMS-Organiza\%C3\%A7\%C3\%A3o-Mundial-da-Sa\%C3\%BAde/constituicao-da-organizacao-mundial-da-saude-omswho.html>. Acesso em: 18 jun. 2015.

PARACELSUS. On miner's sickness and other miner's diseases. In: PARACELSUS. Four teratises of Theuphrastus von Hohenheim called PARACELSUS. Baltimore, Johns Hopkins Press, 1941. p. 43-126.

ROLNIK, Raquel. A cidade e a lei: legislação, política urbana e territórios na cidade de São Paulo. São Paulo: Studio Nobel; Fapesp, 1997.

SAMPAIO, José Adércio Leite. Da cláusula do não retrocesso social à proibição de reversibilidade socioambiental. In: FILHO, Robério Nunes dos Anjos (Org.). Direitos Humanos e Direitos Fundamentais. Salvador: Juspodivm, 2013.

SANTA CATARINA. Atlas Brasileiro de Desastres Naturais 1991 a 2010, volume Brasil. Universidade Federal de Santa Catarina, Centro Universitário de Estudos e Pesquisas sobre Desastres. Florianópolis, 2012.

SCHÄFFER, Wigold Bertoldo et al. Áreas de preservação permanente e unidades de conservação \& áreas de risco - o que uma coisa tem a ver com a outra? Brasília, 2011. Disponível em: <http://www.mma.gov.br/estruturas/202/_publicacao/202_publicacao01082011112029. pdf>. Acesso em: 18 jun. 2015.

SHRADY, Nicholas. O último dia do mundo: fúria, ruína e razão no grande terremoto de Lisboa de 1755. Trad. Paula Berinson. Rio de Janeiro: Objetiva, 2011. 
THOMÉ, Romeu. O Estado democrático de Direito no contexto da sociedade de risco: a aplicação da cláusula de vedação ao retrocesso socioambiental como instrumento de transição para uma nova modernidade. 2013. Tese (Doutorado em Direito) - Faculdade Mineira de Direito, Programa de Pós-Graduação em Direito da Pontifícia Universidade Católica de Minas Gerais, Belo Horizonte, 2013.

TRINDADE, Antônio Augusto Cançado. Tratado de direito internacional de direitos humanos. Porto Alegre: Sérgio Antônio Fabris, 1999. Vol. II.

TUCCI, Carlos E. M. Gestão de águas pluviais urbanas. Brasília: Ministério das cidades, 2005.

Recebido em: 9/11/2016

Aceito em: 14/12/2016 